\title{
Overview of the physiological changes and optimal diet in the golden age generation over 50
}

\author{
Doreen Gille
}

Received: 7 September 2009 / Accepted: 17 February 2010/Published online: 21 March 2010

(C) European Group for Research into Elderly and Physical Activity (EGREPA) 2010

\begin{abstract}
Basically, our lifespan is determined genetically. However, several other parameters such as the environment, lifestyle and diet have a high impact on living in the best of health. Many older persons suffer from various diseases, which often cannot be avoided; however, their development can be postponed and symptoms can be mitigated by a balanced diet, moderate physical activity as well as a healthy lifestyle. These diseases are, for example, sarcopenia (degenerative loss of muscle mass), osteoporosis (decomposition of bone structure), digestive restrictions, sensory impairment, water imbalance or a compromised immune system. Psychological modifications, obesity and loss of weight also commonly occur in older adults. To define an adequate diet for elderly between the ages 50 and 80 is difficult, even impossible, because the nutritional requirements differ between the dynamic quinquagenarian and the frailer eighty-year-old. However, several studies have shown that sufficient consumption of high-quality proteins, calcium, vitamin $\mathrm{D}$, anti-oxidative food compounds, water as well as adapted energy values and nourishment with high-nutrient density in combination with physical activity especially help one to remain healthy to a great age. The cornerstone of healthy ageing is the maintenance of normal bodyweight in order to prevent the development of diseases such as osteoporosis, coronary heart disease or diabetes type 2. This publication will review the physiological changes that occur with advanced
\end{abstract}

\section{Gille $(\triangle)$}

Federal Department of Economic Affairs FDEA,

Agroscope Liebefeld-Posieux ALP,

Schwarzenburgstrasse 161,

3003 Bern, Switzerland

e-mail: doreen.gille@alp.admin.ch age and consequential nutritional recommendations for elderly persons.

Keywords Ageing · Physiological changes · Nutrition · Nutrient requirements $\cdot$ Elderly

\section{Introduction}

The steadily growing elderly population expects and is expected to remain healthy, active and fit as long as possible. The reasons for the increase in size of this age group are manifold - a decrease in infant mortality, adequate food supply, improved medical services accessible to all social classes of the population and the successful fight against contagious diseases through new medical technologies or more effective drugs. These are only some of the positive developments that lead to longevity. In many cases, a lengthening of life is accompanied by loss of independence, mobility, sensory faculties, as well as increasing disabilities and functional impairments including cardiovascular disease, arthritis, osteoporosis, neurodegenerative disorders or cancer [1]. In order to attain a great age in the best of health, the elderly are not only urged to do sports and remain physically and mentally active, but also to maintain a healthy diet. However, many elderly people fail to consume a balanced diet, which provides them adequate amounts of macro- and micronutrients as well as energy. On the one hand, this may be due to psychological and economic changes such as loneliness, depression, low income or a small pension, lack of cooking skills and suspicion of new foods. On the other hand, nutritional needs of elderly persons change due to various physiological modifications, which occur with aging (e.g., body composition, the gastrointestinal tract, water balance and bone health). Often, they do not know about 
these changes and fail to adapt their caloric needs, which results in an imbalanced diet. Thus, it is of utmost concern to inform and elucidate older people about a proper lifestyle and diets for healthy ageing.

\section{Body composition and caloric needs}

A commonly occurring change-independently of whether the person is of normal weight, underweight or overweightis sarcopenia, which is a degenerative loss of active skeletal muscle mass accompanied by the replacement of muscle fibres with fat or even connective tissue. Its multifactorial aetiology includes protein undernutrition, rheumatoid arthritis, Parkinson's disease, chronic infections or inflammation [2]. Since body fat tissue shows no significant metabolic activity, this shift reduces the basal metabolic rate and finally the total energy requirements of older people. Decreases in vitality, strength, immune-activity and mobility are further physiological sequelae of these changes [3] as well as the elevated risk of developing obesity, which especially affects the younger elderly ("sarcopenic obesity") $[3,4]$. Many inflammatory cytokines, such as tumour necrosis factor, interleukin-6 and C-reactive protein originate from this adipose tissue [5]. In addition, these cytokines accelerate muscle catabolism and contribute to the vicious cycle of sarcopenic obesity [6].

Another unfavourable structural alteration is the redistribution of fat tissue from peripheral to visceral, which in turn leads to cardiovascular disease, diabetes, impaired glucose tolerance [7] and high amounts of inflammatory cytokines [5]. Finally, the elderly can prevent these occurrences by consuming protein-rich foods (especially animal protein) with a high-nutrient density. This ingestion favours the synthesis of muscle tissue and counteracts the proliferation of adipocytes. A further approach to prevent drastic structural alterations is - depending on the physical activity level of the individual - the adaptation of food energy values. Generally, it is postulated that caloric ingestion should be reduced by $10 \%$ between the ages 50 and 75 with an additional $10-15 \%$ after 75 . Over consumption (plus 500$700 \mathrm{kcal} /$ day) and overweight are not the only phenomenon. Negative energy intake (minus 600-1,000 kcal/day), which mainly affects individuals over 75 , leading to malnutrition and loss of weight, also plays an important role in elderly nutrition. This may cause undesirable effects such as catabolic metabolism, including losses of muscle and organ mass and functions, symptoms of malnutrition and a dramatic loss of bone mass.

An optimal energy balance has a high impact on elderly health and well-being. Elderly nutrition should especially focus on an adequate supply of minerals, vitamins, proteins and nutrient density without an energy overload. The daily recommendations are summarised in Table 1; the functions and importance of minerals and vitamins are shown in Figs. 2 and 3.

Unfortunately, some bodily functions such as a decline in cardiac output, lung capacity and kidney function can only be slightly improved by nutrition or lifestyle improvements [10].

\section{Fat, protein and carbohydrate metabolism}

\section{Changes in protein metabolism}

Proteins are essential nutritional compounds - not only for the elderly population. The reason for their necessity is that 8 of the 20 constituent amino acids cannot be synthesised by the human organism and, therefore, have to be provided through food. Dietary protein affects multiple physiological mechanisms, particularly muscle metabolism by stimulating muscle protein synthesis from amino acids [11]. The amount of new muscle protein depends on the quantity and quality of ingested amino acids [12]. Whey and caseins from milk as well as beef proteins are rich in essential amino acids and are thus high-quality sources [13, 14]. Researchers showed that the ingestion of small amounts of amino acids results in lower muscle protein synthesis in the elderly than in younger persons. This might also explain the development of sarcopenia. Elderly people can reduce the loss of body protein by increasing the amount of dietary protein intake [15]. Several studies even showed that a high quality of ingested proteins elevates lean body mass and improves strength and physical function in elderly persons [16-18].

A high protein intake also stimulates the secretion of insulin-like growth factor 1 (IGF-1) - a compound which has been shown to be lower in the elderly [19]. Low levels of IGF-1 are thought to be responsible for diminished protein synthesis rates and higher losses of muscle mass [20].

In addition, there are reports in the literature on the beneficial effects of high-quality protein intake on bone stability by increasing bone mineral density and its positive influence on calcium metabolism [21]. Recent intervention studies even demonstrated improvement in hypertension and endothelial function of the arteries with adequate amounts of protein $[22,23]$.

All these important functions show the necessity for a satisfactory supply of protein. Exact intake recommendations for the elderly are still not available because of a lack of methods for their determination and numerous influencing individual factors, such as variable lean body mass or physical functions, but scientists believe that the recommendation for adults ( $0.8 \mathrm{~g}$ high-quality protein/kilogram body weight/day) is inadequate to maintain lean body mass in healthy elderly individuals [24]. To receive enough essential amino acids, researchers recommend that older people consume 1-1.5 g 
Table 1 Daily dietary recommendations for macro- and micronutrients for the elder generation $50+$

A + symbolizes that the intake should be increased in comparison to younger adults; - means that the substance is not required in higher doses in the elderly

Source: D-A-CH reference values [8]

\begin{tabular}{|c|c|c|}
\hline & Recommendations & Comments \\
\hline Energy - & $\begin{array}{l}\text { Women, } 1,800-2,000 \mathrm{kcal} / \text { day } \\
\text { Men, } 2,300-2,500 \mathrm{kcal} / \text { day }\end{array}$ & \\
\hline Protein + & $\begin{array}{l}0.8-1.0 \mathrm{~g} / \mathrm{kg} \text { body weight } \\
44-58 \mathrm{~g} / \text { day }\end{array}$ & High quality proteins in milk and meat \\
\hline Fat - & $30 \%$ of total energy & $\begin{array}{l}\leq 10 \% \text { from saturated fat; } \leq 300 \mathrm{mg} / \text { day } \\
\text { dietary cholesterol, !!no complete waiving of fat!! }\end{array}$ \\
\hline Carbohydrates - & $50 \%$ of total energy/day & With low glycemic indexes \\
\hline Fibre + & $20-35 \mathrm{~g} /$ day & Fruit and vegetables, cereals, legumes \\
\hline Vitamin $\mathrm{C}-$ & $100 \mathrm{mg} /$ day & Fruit and vegetables \\
\hline Vitamin D + & $5-10 \mu \mathrm{g} /$ day & $\begin{array}{l}\text { Exposure to sunlight and consumption of vitamin } \\
\text { D-rich food (esp. fish and fortified skim milk) }\end{array}$ \\
\hline Vitamins B12+ & $3 \mu \mathrm{g} /$ day & Component of lean red meat, chicken, skim milk \\
\hline Folate - & $400 \mu \mathrm{g}$ folate equivalent/day & Green vegetables, wheat, beef liver \\
\hline Iron - & $10 \mathrm{mg} /$ day & Meat, legumes, nuts \\
\hline Zinc - & $7-10 \mathrm{mg} /$ day & Red meat, oysters, wheat germ, whole grains \\
\hline Calcium + & $1,000 \mathrm{mg} /$ day & Milk and dairy products \\
\hline Magnesium + & $300-350 \mathrm{mg} /$ day & Nuts, whole grain \\
\hline Water & Approx. $1.5 \mathrm{~L} /$ day & \\
\hline
\end{tabular}

protein (especially from animal sources because of their high contents of essential amino acids) per kilogram body weight per day, but this proposal remains to be verified [3].

\section{Carbohydrate metabolism}

The major condition for intact glucose homeostasis in both older and younger individuals is a balance between insulin secretion and tissue sensitivity to insulin. Normally, after ingestion of simple carbohydrates, plasma glucose levels rise, inducing the $\beta$-cells of the pancreas to release insulin. This hormone is - besides other functions - responsible for the uptake of glucose in muscles, liver and adipose tissue. Many reports have shown that the insulin sensitivity of tissues decreases with advanced age leading to hyperinsulinaemia, hyperglycaemia, and in many cases, even to diabetes type 2 [25]. The impaired carbohydrate metabolism may be due to (1) ageing, including the physiological changes of the organism, (2) nutrition, (3) other age-related variables such as hypertension, low physical activity levels, dyslipidiaemia or (4) obesity.

On the one hand, several studies demonstrated that age has little, if any effect on fasting glucose and insulin levels in humans [26-28], and that the quantity of insulin secretion does not significantly differ at different ages $[29,30]$. But on the other hand, there is substantial evidence that increasing age is associated with decreased glucose tolerance. This might be partly explained by higher body weight, which is a commonly occurring phenomenon amongst the elderly, and studies have shown that overweight individuals suffer more from diabetes and impaired glucose tolerance than persons of normal weight [7].
Reports from the literature show that approximately $20 \%$ of the elderly are affected by diabetes type 2 , where a pre-existing condition is insulin resistance syndrome. This syndrome mainly arises from muscle metabolic dysfunction and changes in body composition [31, 32]. These dysfunctions and shifts are accompanied by a decreased metabolic function of the whole metabolism (especially mitochondria) leading to reduced overall activity [33]. To prevent these adverse effects, older individuals should minimise their intake of simple carbohydrates and consume foods with low glycemic indexes, such as fibre-rich, poorly sweetened nourishment. In particular, a combination of such a diet with high levels of exercise is an effective means of reducing the risk of diabetes type 2 ; this would preserve pancreatic $\beta$-cells and limit the amount of released insulin because of lower plasma glucose levels.

\section{Fat metabolism}

As already mentioned, ageing is associated with many physiological modifications including an accumulation of body fat. Researchers define the size of adipose tissue mass as the balance between the release of lipid substances (i.e. free fatty acids) from adipose tissue and their oxidation by respiring tissues. The increase of body fat in elderly individuals might be explained by the release of high amounts of free fatty acids from adipose tissue, the reduced capacity of respiring tissues (e.g. muscles) to oxidise free fatty acids at rest [34], following a meal [35] and during exercise [36] or even both. However, there is a lack of expert knowledge on the exact causes and development of 
these metabolic processes. Figure 1 shows the age-related changes in free fatty acid metabolism in older humans.

Until now, few animal or human studies have shown that ageing affects the stimulation, release and activity of fat metabolism-relevant hormones with a serious negative impact on the rate of lipolysis, as well as whole body composition [38]. One reason for this occurrence might be the age-related reduced insulin release from pancreatic tissue. Insulin is not only an important hormone in carbohydrate metabolism, but also plays a fundamental role in inhibiting and regulating the generation of free fatty acids from adipocytes. In the early 1990s, Bolinder et al. were already able to substantiate that ageing is accompanied by reduced sensitivity of the anti-lipolytic effect of insulin in adipocytes [39]. The dose-dependent suppression of free fatty acids by insulin is also decreased in elderly persons [37]. Finally, insulin resistance - a common occurrence in older people - may be responsible for a high amount of free fatty acids and subsequent modifications of metabolism.

The reduction in the capacity to oxidise fat and/or the size of metabolically active tissue may be, as already mentioned, a further reason for an accumulation of adipocytes in older humans. A loss of fat-free organ mass might be due to sarcopenia, a disease which is very common in the elderly.

Although muscles are not the only tissues with oxidising capacities, they are the most studied - especially during exercise. The focus of studies mostly concentrated on muscle enzymes and their changes in activity and concentration. Researchers could show that enzymes involved in $\beta$-oxidation of fatty acids (e.g. 3-hydroxyacyl-CoA dehydrogenase) and oxidative metabolism enzymes (citrate synthase, succinate dehydrogenase) decreased with age, leading to decreased fatty acid oxidation [40, 41]. Another partial explanation for the diminished oxidising capacity of fat-free tissue is the absence of exercise in older persons [36]. In several studies, the elderly were exposed to physical training. The results revealed that exercise improved the activity of enzymes and fat oxidation [36, 40, 42, 43]. Many questions on this topic still remain unanswered, but it is an incontrovertible fact that physical exercise and adapted energy values reduce the accumulation of free fatty acids.

As regards nutrition for the elderly, about $30 \%$ of the daily energy should derive from total fat, less than $10 \%$ from saturated fat and less than $300 \mathrm{mg} /$ day dietary cholesterol. However, fat should not be completely removed from the diet since it also serves important functions in the human body, for example: (1) as a carrier of vitamins and aromas, (2) as a contributor to satiety or (3) as a provider and reserve of energy [44]. Furthermore, conjugated linoleic acids improve body composition [45], and essential fatty acids are precursors of hormones and mediators [46].

\section{Changes concerning the gastrointestinal tract}

Physiological changes of the gastrointestinal tract

All digestive organs undergo age-dependent alterations, and most of them take place in the stomach [47]. The blood supply to the stomach mucosa deteriorates and the inner epithelium loses activity. With greater age, the regeneration

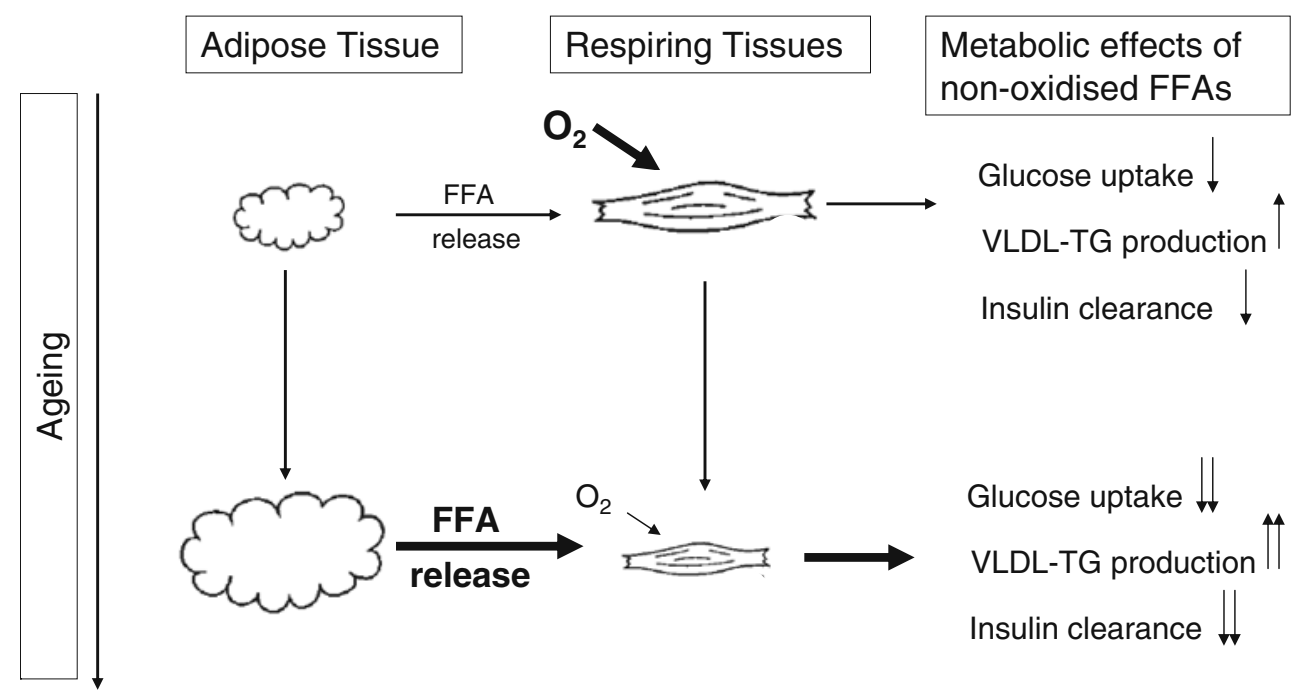

Fig. 1 The figure presents the age-related changes concerning the release of free fatty acids (FFA) and the capacity of tissues to oxidise them. The metabolic effects of non-oxidised free fatty acids are also shown. Advancing life-time is associated with an increase in adipose tissue, a decrease in the mass of oxidative tissue and its capacity to oxidise fat $\left(\mathrm{O}_{2}\right)$. The amount of non-oxidised free fatty acids increases in the elderly because of the enhanced release of free fatty acids in excess of the energy needs or rather the oxidative capacity of respiring tissues. Several adverse metabolic effects follow from non-oxidised FFAs (Figure adapted from Toth et al. [37]) 
of cells is limited by a decreased rate of cell division and increased cell loss. These disabilities induce serious consequences, such as reduced gastric acid production [48]. This, in turn, diminishes the bioavailability of several minerals $(\mathrm{Ca}, \mathrm{Fe})$ and vitamins, facilitates bacterial growth (e.g. Helicobacter pylori) and reduces the formation of the "intrinsic factor" which is responsible for the absorption of vitamin B12 [47]. Stomach motility also decelerates, and gastrointestinal satiety factors increase in activity, leading to reduced appetite in the elderly. Further consequences are atrophy of tissue, ulceration and an overall limitation of functions. Usually, these alterations are not noticeable since they proceed slowly. In the beginning, the human organism can compensate for mineral, vitamin and nutrient deficiency by releasing reserves. But finally, reserves are depleted and physiological sequelae, such as anaemia or malnutrition or an overall declined physical state occurs.

The small intestine is basically affected by two types of alteration: on the one hand, a decline in organ mass (e.g. liver, pancreas) and on the other hand, an atrophic structural change of the mucous membrane. Thus, the mucosal cells exsiccate, and the inner layer of intestine becomes scaly, resulting in impeded absorption of nutrients. The decrease in liver and pancreas' organ mass finally leads to reduced release of bile acids and digestive enzymes, such as lipases, both of which are important factors in fat digestion. Moreover, connective tissue replaces active cells of the organs of metabolism, particularly the detoxification capacity of the liver is perturbed. Furthermore, ageing decelerates gut motility, leading to a higher frequency of obstipation.

Other organs of the gastrointestinal tract (GIT) are also submitted to changes during ageing, but the magnitude of alteration is more or less unimportant and functionally not relevant compared to the changes in the stomach and small intestine. However, for the most part, the digestive activity and the capability of nutrient absorption in elderly persons remain sufficient [47].

\section{Changes in macronutrient absorption in the GIT}

It has been shown that protein loss in faeces does not increase in older individuals, which means that protein absorption is not impaired, even if it is slower in comparison to younger persons [49]. Reports from the literature show that there are difficulties in evaluating changes in carbohydrate absorption in the elderly. This is due to the enormous numbers of bacteria, which multiply in the intestines of older persons since they suffer from hypochlorhydria, a deficiency of hydrochloric acid in the stomach [50]. Thus, the carbohydrates are fermented (especially in the colon) instead of being digested and absorbed in the jejunum [51]. This fermentation is accompanied by flatulence, diarrhoea, obstipation and abdominal cramps.
Fat absorption is not greatly restricted by physiological changes in the gastrointestinal tract, although some enzymes (e.g. lipases) are less active with advancing age.

\section{Water balance}

Water is a key compound in sustaining human intra- and extracellular metabolism at any time of life. For adults and also for the elderly [8], 1.5-2 L of water per day are recommended. But dehydration in humans of the older generation is frequent and can be fatal if undiagnosed [52]. During ageing, the decline in lean body mass is accompanied by a decrease in the water content of the organism. This decrease in water can be up to $4 \mathrm{~L}$ of total body water for men and $6 \mathrm{~L}$ for women (from the age 20 to 80 ). However, hydration of the fat-free mass is not influenced by age. In addition, the lack of sensation of thirst and the fact that people forget to drink due to reduced cognitive and visual functions at greater age can induce total water imbalance. The fear of incontinence or prostate problems also facilitates the limitation of water ingestion. A poor supply of water is associated with infections, decreased endurance, a risk of heat exhaustion, mental confusion, lassitude, muscular weakness or even death [53]. Notably, a reduced water supply negatively influences the electrolyte balance leading to cardiovascular and hypertension disturbances as well as impaired kidney performance [54].

\section{Perturbed tasting and smelling}

Humans have five different important senses to perceive the environment: vision, hearing, feeling, smelling and tasting. At the age of 25, some of these senses are already reduced in quality. Although hardly noticeable, seeing and hearing become limited. At the age of 55, the deterioration becomes more perceivable. However, in general, before 60 , the elderly do not notice reduced olfactory or gustatory functions. The loss of taste is due to a decline in olfactory perception and a reduction in the tongue papillae for sweet, salt, bitter and sour [55]. Thus, threshold values increase [56], which may even result in a change in food patterns and choice of groceries. This often leads to an overconsumption of unhealthy sweet and salty foods with crucial impacts on elderly metabolism. But taste disorder is not only due to the ageing process. Drugs, Alzheimer's disease or stroke can also cause a reduction in taste sensation. These diseases lead to changes in the oral mucosa (often swelling), the quantity of salivation as well as caries and tooth loss. Fifty percent of the elderly suffer from a deficit of saliva and xerostomia (dryness of the mouth). All these alterations result in a loss of appetite, difficulties in 
swallowing and chewing and bring about a loss in the pleasure of eating. The loss of teeth especially is considered to be one of the main reasons for an unhealthy diet because of the disability to eat, for example, fruit, vegetables and other solid foods [57].

\section{Osteoporosis, calcium and vitamin D}

Several factors are responsible for developing osteoporosis; a disease accompanied by a decrease in bone density and bone mass leading to a dangerously increased risk of various fractures. Osteoporosis especially affects the femoral neck, hands and backbone. Calcium and vitamin D deficiency, but also drugs, changes in hormone levels during ageing, gastric diseases and genetics are reasons for the loss of bone structure [58]. Since resultant fractures may often cause mobility restrictions, long-term care dependency or even death, it is of substantial relevance to combine an adequate supply of calcium (Ca) and vitamin D (not only during childhood and adolescence, but throughout the whole of life) with a high level of physical activity.

In the past, several studies demonstrated that a high intake of calcium slows down the age-dependent degradation of bones and helps to maintain bone health. Ideal sources of this mineral are milk and dairy products as they also contain $\mathrm{Ca}$ absorption-enhancing compounds such as lactose or phospho-peptides [59, 60]. Additionally, scientists have shown in animal studies that milk boosts calcium storage in bones more effectively and longer than $\mathrm{Ca}$ supplements. Researchers concluded that the positive effects result from a decrease in bone resorption through direct interaction with osteoclasts (bone-absorbing cells) as well as simultaneous stimulation of cell proliferation and collagen synthesis in osteoblasts (bone-forming cells) [61].

Similarly to calcium, vitamin D is also a key compound regarding the maintenance of calcium metabolism and bone health. Furthermore, reports from the literature describe its influence on immune functions, cell differentiation, insulin release and the secretion of thyroid hormone [62]. This essential compound can be synthesised by skin during exposure to sunlight (ultraviolet) or ingested via fatty fish and milk. However, ageing reduces vitamin D production by different factors. On the one hand, 7-dehydrocholesterol, which is a precursor of the vitamin, is less concentrated in elderly persons [62]. On the other hand, the rate of vitamin synthesis by ageing skin decreases. Furthermore, the elderly stay more and more rarely outdoors, and consequently, exposure to sunlight decreases [63]. In the past, researchers ascertained that $60 \%$ of hip-fracture-patients suffer from extensive vitamin $\mathrm{D}$ deficiency, whereas an adequate daily vitamin D supply would even decrease the risk of hip fracture by $25 \%$ [64]. Other nutritional compounds concerning bone health are proteins, which seem to interact synergistically with calcium [3] and in addition increase bone mineral density. The enhancement of muscle mass by physical exercise and high protein intake contribute in part to the static and dynamic balance of the elderly leading to a minimised risk of accident and bone fractures [21]. Magnesium, a regulator of active $\mathrm{Ca}$ transport, and vitamin $\mathrm{K}$, an important co-factor for several bone-proteins, are also compounds which improve bone health $[65,66]$.

Despite all these preventive measures, it is not possible to avoid bone degradation completely - but at least, it can be limited and decelerated, especially by increasing the consciousness of this disease in adolescents and young adults.

\section{Coronary heart disease and metabolic syndrome}

Although some of the chronic diseases of the elderly occur as a result of the ageing process, lifestyle factors are also important. An absence of physical activity and inappropriate diet are the major modifiers of risk factors leading to coronary heart diseases (CHD), obesity, diabetes and osteoporosis [1]. Coronary heart disease and stroke are the most frequent causes of mortality and morbidity in older adults [67]. The risk factors are widespread and include obesity, dyslipidaemia, hypertension and diabetes as parameters of the metabolic syndrome, but also smoking and low levels of physical activity $[68,69]$. In the course of normal ageing, the vascular walls thicken leading to the development of hypertension and decreased maximal heart rate under stress. Further occurrences are endothelial damage, fibrotic changes of the arterial capillary, reduced elasticity of the vascular walls and diminished blood flow. Finally, these arteriosclerotic changes may lead to heart attacks and strokes.

A reduced intake of total fat is a cornerstone in reducing the risk for CHD, including arterial damage, lipoprotein disorders or high blood pressure. Furthermore, helpful compounds against CHD are folate, vitamins B6 and B12, omega-3 fatty acids, which decrease platelet aggregation, vitamin $\mathrm{C}$ and $\mathrm{E}$ and phytochemicals, which are antioxidants for lipoproteins, DNA and cell membrane phospholipids $[70,71]$. Other vitamins and their functions, which are often deficient in the elderly, are summarised in Fig. 2.

\section{Immune system}

Prolonged age is associated with increased inflammation and oxidative stress or free radicals which are generated during normal physiological reactions such as respiration, immune reactions and energy metabolism [72]. The human body has developed several mechanisms to remove free 
Fig. 2 The figure shows a variety of vitamins and their functions [9]. Older individuals are often deficient in these vitamins

Fig. 3 The importance and functions of magnesium, potassium, iodine, zinc and calcium for various clinical and physiological parameters for the elderly are shown [9]. Elderly individuals often suffer from a lack of these five minerals

\section{Vitamin B6}

Vitamin B1

- control of energy and carbohydrate meatabolism

- adherence of functionality of cardiovascular system and nervous system
- metabolism of amino acids

- synthesis of neurotransmitter

- synthesis of precursors for hemoglobin

- synthesis of antibodies and leukocytes

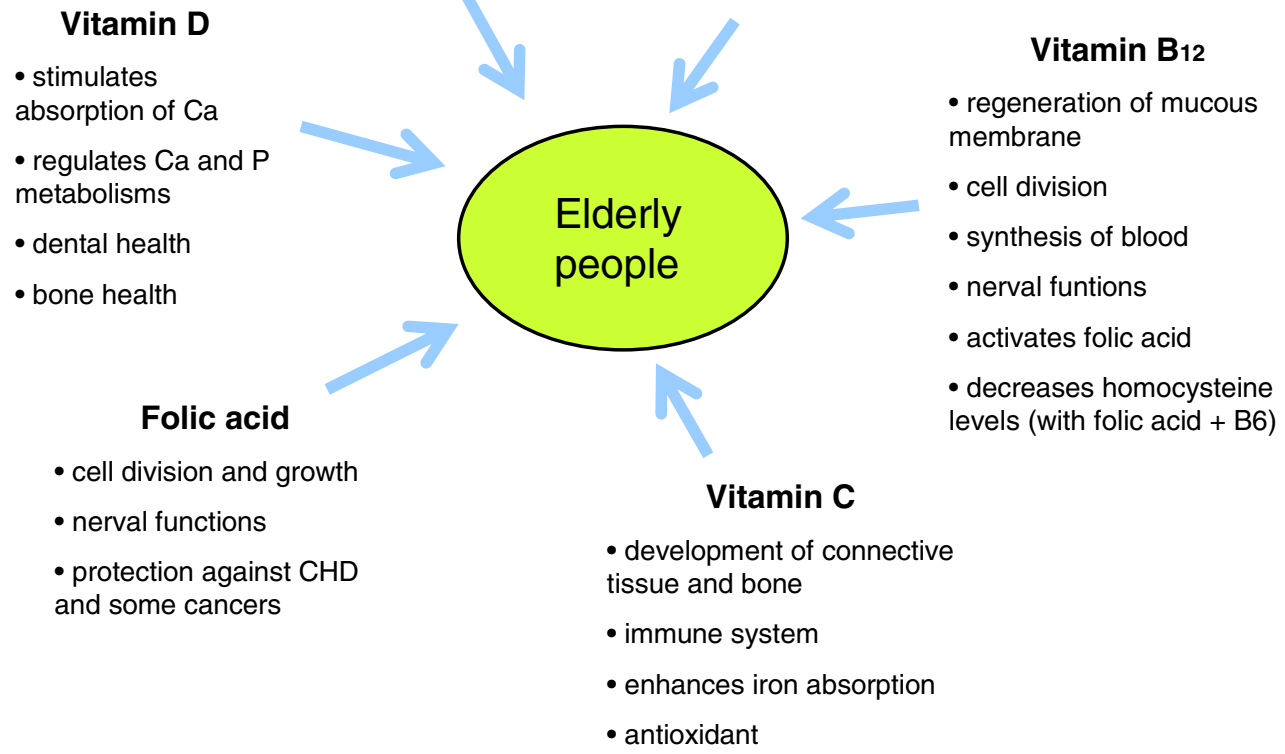

Magnesium

- nerval functions

- muscle contraction

- stabilisation of bone tissue

- dental health

Calcium

- activates enzymes

- bone health

- synthesis of DNA

- dental health

- nerval functions

- muscle activation

- blood clotting

\section{Potassium}

- regulation of water houshold, osmotic pressure and acid-base metabolism - nerval functions
Zinc

- immune system

- appetite

- wound healing

- reducing oxidative stress

- retinal health
- muscle activation

- cell growth 
radicals and to find the optimal balance between oxidative and anti-oxidative capacities. However, the anti-oxidative capacities are more and more insufficient with ageing, leading to increased cell damage. As regards the immune function, there is evidence for a decline in primary and peripheral lymphoid tissue. These processes are accompanied by thymic atrophy and the replacement of hematopoietic bone marrow by adipose tissue. Furthermore, ageing is characterised by impaired activity of immune defence and functional deficits of immune cells [73]. T-cells, for example, release smaller amounts of cytokines and B-cells produce much less antibodies. In addition, the elderly are more vulnerable to infections and tumour formation [74].

It is well-recognized that a balanced diet has a beneficial impact on the immune system. Trace elements (selenium, zinc, iron) and vitamins (A, E, C) as well as polyunsaturated omega-3 fatty acids are vitally important. An adequate supply of these micronutrients can improve the oxidative balance. On the other hand, they also enhance the immune function by protecting the immune cells from reactive oxygen and nitrogen species, which are generated by the organism during defence against pathogens and cell respiration, for example. However, the intake of micronutrients via a balanced nutrition especially seems to have better effects on immune health than high dosage supplements $[75,76]$.

Since nutrition also influences body composition, it can also decrease the risk of increased inflammatory response by decreasing the proportion of fat to lean body mass. Also amino acids, the modules of proteins, contribute to the maintenance of an intact immune system by ensuring the generation of the scavenger glutathione, for example. A high impact on beneficial intestinal bacteria, which boost immune properties, could be demonstrated by synbiotica (probiotica and prebiotica) [77].

\section{Conclusion-which diet for the aged?}

All these explanations point out that lifestyle and nutrition throughout life have a great impact on the ageing processes. A balanced diet in childhood and adolescence already contributes to high life expectancy and low susceptibility to illness. One of the most important factors for continual good health over the years is the prevention of being overweight, underweight or obese since these changes lead to many life-time-reducing diseases such as diabetes type 2, hypertension, dyslipidaemia, cardiovascular disease or osteoporosis. A useful and effective way for weight reduction is a combination of nutrition (food with high-nutrient density and low energy values, with low glycemic indexes, beneficial fatty acids and diets with a high anti-oxidative potential) and physical activity with the aim of loosing fat and gaining muscle mass. Fruit and vegetables can be especially recommended because of their anti-oxidative components as well as their vitamin contents. Also, foods rich in fibres have beneficial impacts on health. Of great importance are protein-rich foods such as milk/dairy products and moderate amounts of meat [78]. Furthermore, the elderly must have an adequate supply of water as well as minerals and vitamins, whose functions are shown in Figs. 2 and 3. Besides all these recommendations, older persons should not waive delicious foods with refined taste, which they should eat with pleasure.

\section{References}

1. Khaw KT (1997) Healthy ageing. BMJ 315(7115): 1090 (25 October)

2. Roubenoff R, Hughes VA (2000) Sarcopenia: current concepts. J Gerontol A Biol Sci Med Sci 55:M716-M724

3. Wolfe RR, Miller SL, Miller KB (2008) Optimal protein intake in the elderly. Clin Nutr 27:675-684

4. Chumlea WC, Baumgartner RN, Vellas BP (1991) Anthropometry and body-composition in the perspective of nutritional-status in the elderly. Nutrition 7:57-60

5. Pedersen M, Bruunsgaard H, Weis $N$ et al (2003) Circulating levels of TNF-alpha and IL-6-relation to truncal fat mass and muscle mass in healthy elderly individuals and in patients with type-2 diabetes. Mech Ageing Dev 124:495-502

6. Schrager MA, Metter EJ, Simonsick E et al (2007) Sarcopenic obesity and inflammation in the InCHIANTI study. J Appl Physiol 102:919-925

7. Goodpaster BH, Krishnaswami S, Resnick H et al (2003) Association between regional adipose tissue distribution and both type 2 diabetes and impaired glucose tolerance in elderly men and women. Diabetes Care 26:372-379

8. Deutsche Gesellschaft für Ernährung, Österreichische Gesellschaft für Ernährung, Schweizerische Gesellschaft für Ernährungsforschung, Schweizerische Vereinigung für Ernährung. Referenzwerte für die Nährstoffzufuhr. Frankfurt: Umschau/Braus, 2000. German/Swiss/ Austrian nutritional recommendations ISBN 978-3-86528-128-9

9. Schweizer Gesellschaft für Ernährung (SGE) (2009) Ernährungsempfehlungen für Erwachsene. http://www.sge-ssn.ch/

10. Geokas MC, Lakatta EG, Makinodan T, Timiras PS (1990) The aging process. Ann Intern Med 113:455-466

11. Wolfe RR (2002) Regulation of muscle protein by amino acids. J Nutr 132:3219S-3224S

12. Bohe J, Low A, Wolfe RR, Rennie MJ (2003) Human muscle protein synthesis is modulated by extracellular, not intramuscular amino acid availability: a dose-response study. J Physiol 552:315-324

13. Tipton KD, Elliott TA, Cree MG, Wolf SE, Sanford AP, Wolfe RR (2004) Ingestion of casein and whey proteins result in muscle anabolism after resistance exercise. Med Sci Sports Exerc 36:2073-2081

14. Symons TB, Schutzler SE, Cocke TL, Chinkes DL, Wolfe RR, Paddon-Jones D (2007) Aging does not impair the anabolic response to a protein-rich meal. Am J Clin Nutr 86:451-456

15. Katsanos CS, Kobayashi H, Sheffield-Moore M, Aarsland A, Wolfe RR (2006) A high proportion of leucine is required for optimal stimulation of the rate of muscle protein synthesis by essential amino acids in the elderly. Am J Physiol Endocrinol Metab 291:E381-E387

16. Solerte SB, Gazzaruso C, Schifino N et al (2004) Metabolic effects of orally administered amino acid mixture in elderly 
subjects with poorly controlled type 2 diabetes mellitus. Am J Cardiol 93:23A-29A

17. Borsheim E, Bui QU, Tissier S, Kobayashi H, Ferrando AA, Wolfe RR (2008) Effect of amino acid supplementation on muscle mass, strength and physical function in elderly. Clin Nutr 27:189195

18. Houston DK, Nicklas BJ, Ding J et al (2008) Dietary protein intake is associated with lean mass change in older, communitydwelling adults: the Health, Aging, and Body Composition (Health ABC) Study. Am J Clin Nutr 87:150-155

19. Kelijman M (1991) Age-related alterations of the growth-hormone insulin-like-growth-factor I axis. J Am Geriatr Soc 39:295-307

20. Ceda GP, Dall'Aglio E, Maggio M et al (2005) Clinical implications of the reduced activity of the GH-IGF-I axis in older men. J Endocrinol Investig 28:96-100

21. Szulc P, Beck TJ, Marchand F, Delmas PD (2005) Low skeletal muscle mass is associated with poor structural parameters of bone and impaired balance in elderly men - the MINOS study. J Bone Miner Res 20:721-729

22. Townsend RR, McFadden CB, Ford V, Cadee JA (2004) A randomized, double-blind, placebo-controlled trial of casein protein hydrolysate (C12 peptide) in human essential hypertension. Am J Hypertens 17:1056-1058

23. Ferrara LA, Innelli P, Palmieri V et al (2006) Effects of different dietary protein intakes on body composition and vascular reactivity. Eur J Clin Nutr 60:643-649

24. Vellas BJ, Hunt WC, Romero LJ, Koehler KM, Baumgartner RN, Garry PJ (1997) Changes in nutritional status and patterns of morbidity among free-living elderly persons: a 10-year longitudinal study. Nutrition 13:515-519

25. Harris MI, Flegal KM, Cowie CC et al (1998) Prevalence of diabetes, impaired fasting glucose, and impaired glucose tolerance in US adults - the Third National Health and Nutrition Examination Survey, 1988-1994. Diabetes Care 21:518-524

26. Maneatis T, Condie R, Reaven G (1982) Effect of age on plasma-glucose and insulin responses to a test mixed meal. $\mathrm{J}$ Am Geriatr Soc 30:178-182

27. Barrettconnor E (1980) Factors associated with the distribution of fasting plasma-glucose in an adult community. Am J Epidemiol 112:518-523

28. Ferrannini E, Haffner SM, Mitchell BD, Stern MP (1991) Hyperinsulinemia - the key feature of a cardiovascular and metabolic syndrome. Diabetologia 34:416-422

29. Chen M, Bergman RN, Pacini G, Porte D (1985) Pathogenesis of age-related glucose-intolerance in man-insulin resistance and decreased beta-cell function. J Clin Endocrinol Metab 60:13-20

30. Pacini G, Valerio A, Beccaro F, Nosadini R, Cobelli C, Crepaldi G (1988) Insulin sensitivity and beta-cell responsivity are not decreased in elderly subjects with normal Ogtt. J Am Geriatr Soc 36:317-323

31. Nair KS (2005) Aging muscle. Am J Clin Nutr 81:953-963

32. Elahi D, Muller DC (2000) Carbohydrate metabolism in the elderly. Eur J Clin Nutr 54:S112-S120

33. Morino K, Petersen KF, Shulman GI (2006) Molecular mechanisms of insulin resistance in humans and their potential links with mitochondrial dysfunction. Diabetes 55:S9-S15

34. Nagy TR, Goran MI, Weinsier RL, Toth MJ, Schutz Y, Poehlman ET (1996) Determinants of basal fat oxidation in healthy Caucasians. J Appl Physiol 80:1743-8

35. Roberts SB, Fuss P, Dallal GE et al (1996) Effects of age on energy expenditure and substrate oxidation during experimental overfeeding in healthy men. J Gerontol A Biol Sci Med Sci 51: B148-B157

36. Sial S, Coggan AR, Carroll R, Goodwin J, Klein S (1996) Fat and carbohydrate metabolism during exercise in elderly and young subjects. Am J Physiol: Endocrinol Metab 271:E983-E989
37. Bonadonna RC, Groop LC, Simonson DC, Defronzo RA (1994) Free fatty-acid and glucose-metabolism in human aging - evidence for operation of the Randle cycle. Am J Physiol 266:E501-E509

38. Toth MJ, Tchernof A (2000) Lipid metabolism in the elderly. Eur J Clin Nutr 54:S121-S125

39. Bolinder J, Ostman J, Arner P (1983) Influence of aging on insulin-receptor binding and metabolic effects of insulin on human adipose-tissue. Diabetes 32:959-964

40. Coggan AR, Spina RJ, King DS et al (1992) Histochemical and enzymatic comparison of the gastrocnemius-muscle of young and elderly men and women. J Gerontol 47:B71-B76

41. Rooyackers OE, Adey DB, Ades PA, Nair KS (1996) Effect of age on in vivo rates of mitochondrial protein synthesis in human skeletal muscle. Proc Natl Acad Sci USA 93:15364-15369

42. Coggan AR, Spina RJ, King DS et al (1992) Skeletal-muscle adaptations to endurance training in 60-yr-old to 70 -yr-old men and women. J Appl Physiol 72:1780-1786

43. Sial S, Coggan AR, Hickner RC, Klein S (1998) Training-induced alterations in fat and carbohydrate metabolism during exercise in elderly subjects. Am J Physiol: Endocrinol Metab 274:E785-E790

44. Biesalski HK, Grimm P (1999) Taschenatlas der Ernährung. Georg Thieme Verlag, Stuttgart

45. Bhattacharya A, Banu J, Rahman M, Causey J, Fernandes G (2006) Biological effects of conjugated linoleic acids in health and disease. J Nutr Biochem 17:789-810

46. Zamaria N (2004) Alteration of polyunsaturated fatty acid status and metabolism in health and disease. Reprod Nutr Dev 44:273282

47. Russell RM (2001) Factors in aging that effect the bioavailability of nutrients. J Nutr 131:1359S-1361S

48. Feldman M, Cryer B, McArthur KE, Huet BA, Lee E (1996) Effects of aging and gastritis on gastric acid and pepsin secretion in humans: a prospective study. Gastroenterology 110:1043-1052

49. Russell RM (2000) The aging process as a modifier of metabolism. Am J Clin Nutr 72:529S-532S

50. Saltzman JR, Kowdley KV, Pedrosa MC et al (1994) Bacterial overgrowth without clinical malabsorption in elderly hypochlorhydric subjects. Gastroenterology 106:615-623

51. Feibusch JM, Holt PR (1982) Impaired absorptive-capacity for carbohydrate in the aging human. Dig Dis Sci 27:1095-1100

52. Weinberg AD, Minaker KL, Coble YD et al (1995) Dehydrationevaluation and management in older adults. JAMA 274:1552-1556

53. Reyes-Ortiz CA (1997) Dehydration, delirium, and disability in elderly patients. JAMA 278:287

54. Mack GW, Weseman CA, Langhans GW, Scherzer H, Gillen CM, Nadel ER (1994) Body-fluid balance in dehydrated healthy older men - thirst and renal osmoregulation. J Appl Physiol 76:16151623

55. Winkler S, Garg AK, Mekayarajjananonth T, Bakaeen LG, Khan E (1999) Depressed taste and smell in geriatric patients. J Am Dent Assoc 130:1759-1765

56. Nordin S, Bramerson A, Bringlov E, Kobal G, Hummel T, Bende M (2007) Substance and tongue-region specific loss in basic taste-quality identification in elderly adults. Eur Arch Otorhinolaryngol 264:285-289

57. Walls AWG, Steele JG (2004) The relationship between oral health and nutrition in older people. Mech Ageing Dev 125:853857

58. Chapuy MC, Arlot ME, Duboeuf F et al (1992) Vitamin D3 and calcium to prevent hip fractures in elderly women. N Engl J Med 327:1637-1642

59. Heaney RP (2000) Calcium, dairy products and osteoporosis. J Am Coll Nutr 19:83S-99S

60. Huth PJ, Dirienzo DB, Miller GD (2006) Major scientific advances with dairy foods in nutrition and health. J Dairy Sci 89:1207-1221 
61. Toba Y, Takada Y, Matsuoka Y et al (2001) Milk basic protein promotes bone formation and suppresses bone resorption in healthy adult men. Biosci Biotechnol Biochem 65:1353-1357

62. Suter PM, Brunner S (2006) Vitamine im Alter-Ausgewählte Aspekte für die tägliche Praxis. Schweizer Zeitschrift für Ernährungsmedizin 4:28-33

63. Brombach C, Ramseyer K (2008) Was essen Schweizer Seniorinnen und Senioren? Transfer (ZHAW), in press

64. Bischoff-Ferrari HA, Willett WC, Wong JB et al (2009) Prevention of nonvertebral fractures with oral vitamin D and dose dependency: a meta-analysis of randomized controlled trials. Arch Intern Med 169:551-561

65. Bonjour JP, Gueguen L, Palacios C, Shearer MJ, Weaver CM (2009) Minerals and vitamins in bone health: the potential value of dietary enhancement. Br J Nutr 101:1581-1596

66. Sojka JE, Weaver CM (1995) Magnesium supplementation and osteoporosis. Nutr Rev 53:71-74

67. Simons LA, Simons J, Friedlander Y, Mccallum J (2001) Cholesterol and other lipids predict coronary heart disease and ischaemic stroke in the elderly, but only in those below 70 years. Atherosclerosis 159:201-208

68. Alexander JK (2001) Obesity and coronary heart disease. Am J Med Sci 321:215-224

69. Bijnen FCH, Feskens EJM, Caspersen CJ et al (1996) Physical activity and cardiovascular risk factors among elderly men in Finland, Italy, and the Netherlands. Am J Epidemiol 143:553-561
70. Weber P, Bendich A, Schalch W (1996) Vitamin C and human health - a review of recent data relevant to human requirements. Int J Vitam Nutr Res 66:19-30

71. Singh RB, Ghosh S, Niaz MA et al (1995) Dietary intake, plasma levels of antioxidant vitamins, and oxidative stress in relation to coronary artery disease in elderly subjects. Am J Cardiol $76: 1233-1238$

72. Sieber C (2007) Biological processes of aging — beginning, course and differentiation from pathological processes. Actuel Ernaehr Med 32(Supplement 2):S136-S139. doi:10.1055/s-2007-970848

73. Burns EA (2004) Effects of aging on immune function. J Nutr Health Aging 8:9-18

74. Gruver AL, Hudson LL, Sennpowski GD (2007) Immunosenescence of ageing. J Pathol 211:144-156

75. Chandra RK (2004) Impact of nutritional status and nutrient supplements on immune responses and incidence of infection in older individuals. Ageing Research Reviews 3:91-104

76. Wouters-Wesseling W, Wagenaar LW, de Groot LCPG, Bindels JG, van Staveren WA (2003) Biochemical antioxidant levels respond to supplementation with an enriched drink in frail elderly people. J Am Coll Nutr 22:232-238

77. Bunout D, Barrera G, Hirsch S et al (2004) Effects of a nutritional supplement on the immune response and cytokine production in freeliving Chilean elderly. JPEN J Parenter Enteral Nutr 28:348-354

78. Wolfram G (2000) Referenzwerte für die Nährstoffzufuhr der DGE, OGE, SGE, und SVE, 1. Auflage 2000. Auflistung und Kommentare der Neuerungen. Ernährungs-Umschau 47:80-85 